\title{
ENHANCING EXPORT PERFORMANCE OF SMALL AND MEDIUM-SIZED ENTERPRISES IN EMERGING MARKETS
}

\author{
DOI: 10.17261/Pressacademia.2019.1075 \\ PAP- V.9-2019(22)-p.100-104
}

Arsalan Safari ${ }^{1}$, Ali Salman Saleh ${ }^{2}$

${ }^{1}$ Qatar University, College of Business and Economics, Doha, Qatar, P.O.Box 2713. asafari@qu.edu.qa, ORCID: 0000-000 2-9324-3321

2 Qatar University, College of Business and Economics, Doha, Qatar, P.O.Box 2713.

asaleh@qu.edu.qa, ORCID: 0000-0003-2869-2232

To cite this document

Safari, A., Saleh, A. S. (2019). Enhancing export performance of small and medium-sized enterprises in emerging markets. PressAcademia Procedia (PAP), V.9, p.100-104

Permemant link to this document: http://doi.org/10.17261/Pressacademia.2019.1075

Copyright: Published by PressAcademia and limited licenced re-use rights only.

\section{ABSTRACT}

Purpose- Although there are various benefits for SMEs to expand their businesses to international markets, there are many obstacles that discourage them to move internationally, especially in emerging markets. This study focuses on the capacity building to enhance SME export activities in an emerging market.

Methodology- Eventhough the latest literature in the area of export performance have focused on firms from the emerging countries, studies in this area are still limited. Earlier research in this area has mostly focused solely on the determinants of exports performance from either internal factors, external factors or both without using adequately potential mediating factors which could affect export performance. This paper develops and tests a holistic framework for SME export considering all aspects of export drivers, and inhibitors. This theoretical framework incorporates and tests three potential mediators (i.e., business strategy, export marketing strategy and innovation strategy) as well.

Findings- The initial data analysis confirms and shows the significant effects of various internal and external firms' determinants on their export performance. The final research finding have significant implications for understanding all key drivers of SME export in Qatar, and it helps policymakers and regulators to improve the current SME ecosystem in Qatar.

Conclusion- The final results of this study can be extended to other emerging markets with similar economic and legal structure.

Keywords: Export performance, structural equation modeling, SMEs, Qatar.

JEL Codes: F23, C12, C21

\section{INTRODUCTION}

Internationalization of SMEs has grown in popularity in recent years and seem to provide the bridge between international business studies and studies in entrepreneurship and small business. Market globalization, rapid technology improvement, government support as well as recent changes to the world economy (market and trade liberalization initiatives) have played a positive role in increasing SMEs' internationalization through exports (Krammer et al., 2018). Their significant contribution to the overall employment and job creation, innovation, and economic restoration is obvious (Westhead et al., 2004). Prioritizing to improve the SMEs' export performance is therefore, become salient within the boundary of export-related research.

This research introduces an integrative theoretical framework that incorporates three potential mediators (business strategy, export marketing strategy and innovation strategy) to investigate the effects of internal and external factors on export performance, highlighting the importance of mediating effects on SMEs to grow and compete in the international arena.

Qatar is a motivating case to investigate given the Qatar economy is largely dependent on the export of natural gas and petroleum, which has considerable volatility. Developing and supporting private sector activities, including Small and Medium Enterprise (SME) development is an important part of the Qatar diversification plan. Due to the small market size of Qatar and its current highly competitive and saturated market in many sectors, businesses need to focus on exporting their products.

\section{LITERATURE REVIEW}


Research on the key determinants of SMEs has attracted a growing amount of interest in the literature over the past few decades because of the importance of SMEs in terms of exports and job creation (Sousa, et al., 2008; Zou and Stan, 1998; Rua et al., 2018; Dhanaraj and Beamish, 2003; Krammer et al., 2018; Anil and Shoham, 2017). These studies contributed to the literature in terms of finding many relevant determinants of export performance and how to measure them. According to Beleska-Spasova (2014), achieving effective export performance is at the core of the tactical legislative procedure for both businesses and other entities. For corporations, successful export performance shows the extent of a firm's goals, both financial and non-financial. Such goals are achieved in the global setting within an agreed period, and they can be evaluated by the appropriateness of the selected export approach, given the internal and external factors (Beleska-Spasova, 2014).

A more specific paper about the case of Qatar was developed by Fernandez and Ali (2015) with an aim to establish the promoters as well as challenges facing small and medium-sized enterprise in Qatar. In this paper, Fernandez and Ali (2015) found the major challenges facing SMEs to include lack of government incentives, socio-cultural barriers, logistical barriers, competition from large companies and lack of access to capital/finances. However, although this study was highly focused on Qatar's case with regard to challenges facing SMEs, it did not have a special interest in their involvement in the export trade.

It is important to mention that in previous studies the research isolated the export performance and its determinants from the nature of domestic market environment and precisely the location. Freeman, Styles and Lawley (2012) clearly pointed out that the metropolitan areas attract more industry players with high intensity for competition. Furthermore, the relationship with clients and suppliers as well as industry and government association is considered to be part of the business networks and is critical for exports. Freeman, Styles and Lawley (2012) also suggested that the survival of the SMEs is dependedant on the combination of collaboration, co-operation and alliances with industry, government and other SMEs.

\section{DATA AND METHODOLOGY}

\subsection{The Proposed Framework and Hypotheses}

Based on the above discussed literature, we have developed a number of hypotheses shown in Figure 1 for SMEs' export in Qatar, and they can be used to test the effects of internal and external constructs or factors on SMEs export performance in Qatar. The firms' export performance as our model's outcome is measured through both objective and subjective measures.

As indicated earlier it is important to note that the existing literature has focused solely on the determinants of exports performance from either internal factors, external factors or both without using adequately potential mediating factors such as Business Strategy (BS), Export Strategy (ES) and Innovation Strategy (IS) which could affect export performance. These three potential mediating factors are yet to be investigated in the export performance business literature. Hence, based on the above studies, we can hypothesize that:

H_1: Internal (managerial and organizational) determinants (X_1i) have indirect and significant impacts on firms' export performance through mediators/strategies.

H_2: Internal determinants (X_2j) have direct and significant impacts on firms' export performance.

H_3: Firms' external determinants $\left(X \_3 k\right)$ have indirect and significant impacts on firms' export performance through mediators/strategies.

H_4: Firms' external determinants (X_4k) have direct and significant impacts on firms' export performance.

H_5: Innovation strategy (a mediator) (X_5) has direct and significant impacts on firms' export performance.

H_6: Export Marketing strategy (X_6) has direct and significant impacts on firms' export performance.

H_7: Business strategy (X_7) has direct and significant impacts on firms' export performance.

Figure 1 shows the potential impacts of all internal and external factors or determinants on SMEs' export performance directly or indirectly through main mediators of innovation strategy, business strategy, and export marketing strategy. This framework shows our research model and hypotheses. The test is conducted using primary data of survey outcomes in Qatar. The survey comprises 38 main questionnaires (with the total of about 100 technical questions) to address and examine all determinants of export performance through SMEs feedback in Qatar. The list of constructs or latent variables include Motivation and Attitude, Int'l Business Knowledge, Export Confidence, Export Commitment, Networking Proactiveness, Power Distance (Foreign Market Similarities), Company's Export Resources, Risk Taking Propensities, Risk Taking Attitude, Perceived Export Barriers, and Government Export Assistance. In the list of latent variables, Innovativeness (Innovation Strategy), Proactiveness (Business Strategy), and Export Marketing Strategy are mediators. While there are some few observed variables that are not significant, majority of them are significant and associated with their latent variables for testing our main hypotheses of the model. 


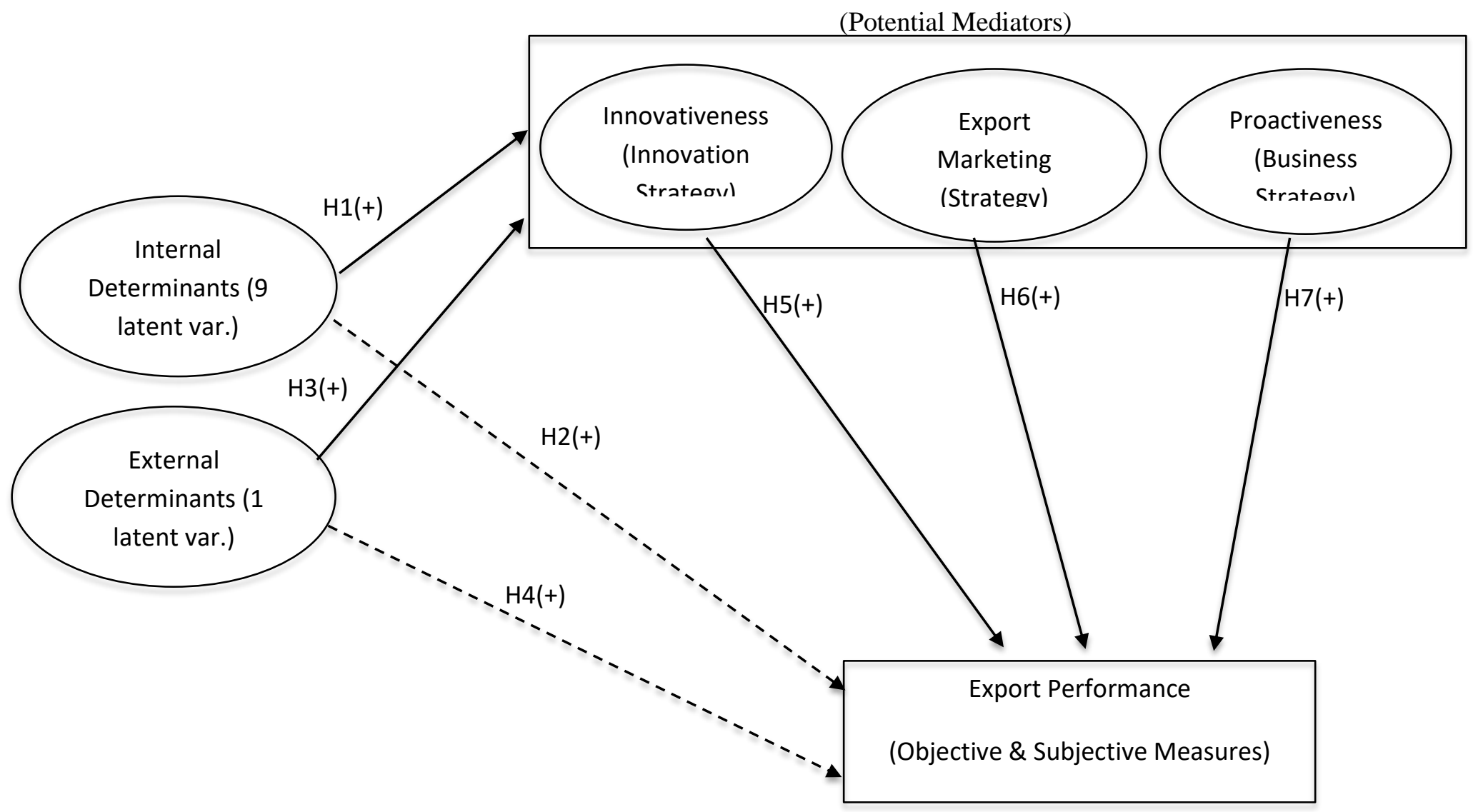

Figure 1: Export Performance Model for Qatari SME Exporters - Research Model 


\subsection{Method and Data}

Empirically, this research develops nine hypotheses, and examines them by using various Qatari sectors data (manufacturing, services and construction) of over 105 SME exporters in Qatar. This research starts with an extensive survey to collect Qatari SMEs opinion regarding their export performance and the effective factors of being a successful exporter of goods or services. The details of survey structure is provided below. This study applies descriptive statistics, Confirmatory Factor Analysis (CFA), and Structural Equation Modelling (SEM) methods for data analysis. The input data is carried out using various statistical softwares for analysis phase. Descriptive statistics help us to highlight the demographic characteristics of Qatari SMEs. They are also helpful to describe the basic features of the data and to summarize the samples and measures using graphical or tabular form of analysis. This analysis forms the basis for our advanced quantitative analysis. The CFA method is applied here to test whether measures of our construct are consistent with our proposed framework of export determinants or factors. In the other word, the method tests whether the data fit the hypothesized measurement model.

The SEM method helps to fit our networks of constructs to data. SEM includes CFA, path analysis, partial least squares path modelling, and latent growth modelling.

\section{FINDINGS}

A frequency distribution analysis is conducted for displaying the frequency of various outcomes of our survey. As indicated in Figure 1, the largest proportion of the SMEs exporters are operating in manufacturing and service industries in Qatar, with $67 \%$ and $10 \%$ respectively. tar. About 48 percent of SME exporters employed between 11-50 employees, 30 percent employed between 51-200 workers, and 16 percent employed between 200-300 workers. Only 3 percent of SMEs employed fewer than 5 workers. This clearly shows that SMEs might be experiencing a different level of business development and has different capacity of employing larger number of workers.

As indicated earlier, the path analysis as well as SEM analysis are applied to examine the fitness of the observed variables (questions) and latent variables (constructs) first, then to test the entire theoretical model shown in Figure 1 above using empirical data collected through Qatari SMEs' exporters. Based on our path analysis outcomes, except for six survey questions (or observed variables) out of 98 questions (or observed variables), the rest of questions confirm strong association with the 15 constructs. These six non-significant observed variables have been eliminated for the SEM analysis of the main models.

The SEM analysis starts with examining the direct effects of the main latent variables on SMEs' export performance without mediators to see how significant is the impact of each internal and external organizational parameters. Based on this analysis outcomes, Export Commitment, Networking Proactiveness, Export Resources, Export Assistance, Risk Taking Attitude and Propensity, Export Confidence, and International Business Knowledge have significant effects on export. However, Networking Proactiveness and Risk Taking Propensity have negative coefficients.

Our SEM analysis of the main theoretical model/framework illustrated in Figure 1 shows that the model with the three strategic mediators of proactiveness, innovativeness and export marketing is more significant than the model without mediators. That means, mediators have significant roles in SMEs export. However, Export Marketing Strategy does not have significant impacts on export even with $90 \%$ confidence level. In the final model, majority of internal and external firms' determinants influence mediators or strategies, and two main mediators of proactiveness and innovativeness affect firms' export performance with high level of confidence. Using mediators in this model also help to examine and validate the causality of latent variables (independent variables or $X^{\prime}$ s) on export (the dependent variable or $Y$ ) not vice versa.

\section{CONCLUSION}

This study developed seven main hypotheses and examined them empirically by using mainly Qataris manufacturing and service sector data of 103 SME exporters across Qatar. The data are analysed via descriptive statistics, Path analysis and SEM techniques to examine observed variables and then test all potential factors affecting SMEs' export performance. Specifically, this study provides suggestions for SME exporters in Qatar to enhance their export performance by focusing directly on effective factors and strategies, which, in turn, would enhance their export performance. SMEs should be more proactive in terms of introducing new products and services and should take the initiatives to compete in order to achieve competitive advantages and growth. SMEs may not be able to do this effort alone without proper government intervention to assist them in being more innovative so they can enter new international markets rather than focusing only on the Middle East markets. In addition, SMEs should be confident and risk taker. They should provide effective training for their staff to improve their international business knowledge, marketing and foreign language communication, among other things.

This comprehensive study contributes both theoretical and empirical insights to the literature by examining the direct and indirect effects of internal and external factors on export performance. Our empirical findings are applicable to SME exporters in Qatar and might be relevant to other emerging countries in the region with similar legal and economic structures. Finally, this study could help policymakers and regulators to improve the current SME environment in Qatar and develop export supporting programs and various incentives to enhance SMEs' export of goods and services, and to help SMEs to overcome their existing obstacles and improve their export activities. Finally, the results of this study can be extended to other emerging markets. Future studies can focus on adding more economies and industries from the region. 


\section{REFERENCES}

Anil, N. K., \& Shoham, A. (2017). Testing an Integrative Model of Export Performance in Turkish SMEs. In The Customer is NOT Always Right? Marketing Orientationsin a Dynamic Business World (pp. 154-154). Springer, Cham.

Beleska-Spasova, E. (2014). Determinants and measures of export performance -Comprehensive literature review. Journal of Contemporary Economic and Business Issues, 1(1), pp. 63 - 74.

Dhanaraj, C and Beamish, P.W (2003). A Resource-Based Approach to the Study of Export Performance. Journal of Small Business Management 41(3), pp. 242-261

Fernandez, R. and Ali, S. (2015). SME contributions for diversification and stability in emerging economies -An empirical study of the SME segment in the Qatar economy. Contemporary Issues in Business and Government. 21, 23-45.

Freeman, J., Styles, C. and Lawley, M. (2012). Does firm location make a difference to the export performance of SMEs? International Marketing Review, 29(1), pp.88-113.

Krammer, S. M., Strange, R., \& Lashitew, A. (2018). The export performance of emerging economy firms: The influence of firm capabilities and institutional environments. International Business Review, 27(1), 218-230.

Rua, O., França, A., \& Fernández Ortiz, R. (2018). Key drivers of SMEs export performance: the mediating effect of competitive advantage. Journal of Knowledge Management, 22(2), 257-279.

Sousa, CMP, Martínez-López, FJ \& Coelho, F. (2008). The determinants of export performance: A review of the research in the literature between 1998 and 2005, International Journal of Management Reviews, vol. 10, no. 4, pp. 343-374

Westhead, P., Wright, M., \& Ucbasaran, D. (2004). Internationalization of private firms: environmental turbulence and organizational strategies and resources. Entrepreneurship \& Regional Development, 16(6), 501-522.

Zou, S. and S. Stan (1998). The determinants of export performance: a review of the empirical literature between 1987 and 1997. International Marketing Review 15(5): 333-356. 